naturally to give up any suitable land for agriculture, but such sites are now unfortunately very few and far between.

Artificial regeneration has been making consider. able strides. The most popular species is mahoe (Hibiscus elatus); but the use of Pinus patula and Eucalyptus saligna has again been partly increased and formed approximately one-third of the area of 620 acres planted during the year. The total area of plantations formed by the Department amounts to 6,348 acres. The general planting programme has now a fairly constant pattern : above 3,000 ft. Pinus patula is planted on the grassland areas and Eucalyp. tus saligna on the old cultivation areas; in the middle-elevation areas, mahoe and broadleaf (Terminalia latifolia) are put on the sites of better soil and Eucalyptus species, Pinus patula and Grevillea robusta on the impoverished sites; in the coastal region mahoe is used in the drier localities and teak on alluvial flats.

\section{INDUSTRIAL RESEARCH ASSOCIATIONS IN GREAT BRITAIN}

$\triangle$ DDRESSING a meeting of the Parliamentary A and Scientific Committee on July 13, Mr. G. L. Bailey, immediate past chairman of the Committee of Directors of Research Associations, said that the total income of the forty-one research associations in Britain to-day amounts to about $£ 4.5$ million, of which about $£ 3$ million comes from industry. The general object of the research associations is to encourage the use of scientific knowledge by industry, including both the acquisition of scientific knowledge and its application. More money is spent on research than on its application, and in his address Mr. Bailey concerned himself mainly with what is done to secure the application of research results in industry, although he instanced the work by Dr. A. J. P. Martin and Dr. R. L. M. Synge on partition chromatography and the new anti-corrosive composition formulated by the British Iron and Steel Research Association as outstanding examples of important achievements in pure research that are to the credit of a research association; the former arose out of a search for methods of analysis suitable for elucidating the chemical composition of wool, and the latter from a long-range detailed study of the corrosion of steel and its prevention.

Much of the research programme of the associations, said Mr. Bailey, is concerned with the development of new materials for a particular purpose or of new processes, and there are also smaller investiga. tions and those relating to methods of testing or evaluation. Apart from the issue of reports or of scientific papers, the associations usually spend 15-20 per cent of their liaison service income on consultations originating in a direct approach from a member firm or arising out of a visit by a liaison officer for a general discussion. Such liaison work, moreover, is now tending to intensify application work at the expense of long-range research generally.

Dr. S. Whitehead, the chairman of the Committee of Directors of Research Associations, who followed Mr. Bailey, referred first to co-operation with universities and technical colleges, to which institutions the research associations make grants amounting to about $£ 80,000$ annually, their policy being usually to seek to interest universities in the inadequately explored portions of fundamental science on which industries are based. The research associations also bear much of the responsibility for scientific representation of their industries abroad, and government departments make great use of them on specialized projects. Mostly Dr. Whitehead's address was concerned with the question of development. Apart from their success in persuading individual members to undertake development, the research associations have sought to foster the group method of sharing the cost of development. During and since the Second World War the Government has successfully used the method of research or development contracts, and research associations have also found the National Research Development Corporation very helpful. The Coal Utilization and the Electrical Research Associations and the Shirley Institute, however, have also formed development companies, and this has two main advantages : the negotiation of commercial agreements and the technical problems of commercial application require a different type of staff and management; and, apart from some convenience over taxation, the development company hopes to make profits, and its finances can be more easily kept separate from that of its non-profitmaking parent. Shirley Developments, Ltd, is concentrating at first on the commereial development and exploitation of instruments, devices and machines developed at the Shirley Institute, whereas Electrical Research Association Patents, Ltd., has largely confined itself to the granting of licences on important patents. Dr. Whitehead claimed that the research associations are at least as good as the best industrial research departments in the number of projects exploited, and that they are actively pursuing all the methods by which scientific discovery can be most rapidly, generally and fruitfully applied.

At the meoting, Sir Reginald Rootes limited his remarks to research in the motor industry, on the basis of which he maintained that the Motor Industry Research Association has fostered co-operation and done much to enable the British industry to keep abreast of its competitors; it provides buildings, research equipment and facilities on its provingground that are more comprehensive than those which individual manufacturers could afford. $\mathrm{He}$ also stressed the importance of adequate financial reserves and of research associations being able to plan their work for some years ahead.

\section{SUB-GRAIN BOUNDARY CORROSION IN HIGH-PURITY ALUMINIUM}

\section{BY M. METZGER}

Columbia University, New York, N.Y. AND

\section{J. INTRATER}

College of Engineering, Rutgers University, New Brunswick, N.J.

DREVIOUS observations of the intergranular corrosion of high-purity aluminium in hydrochloric acid have involved the general high-angle grain boundaries, and only superficial attack of the low-angle and sub-grain boundaries has been noted, except after prolonged anodic treatment ${ }^{1}$. We have observed that the sub-grain boundaries (as well as the low-angle grain boundaries) of properly heattreated specimens are particularly susceptible to 